口特集＜小児の高次脳機能障害と発達支援：ことばに関する障害を中心に>

\title{
自閉症スペクトラムのコミュニケーション障害
}

藤原加奈江

要 約: 自閉症スペクトラムのコミュニケーション障害は語彙, つづり, 音韻などは良好な 一方で複雑な文の理解や暗喻や皮肉の理解が困難であるなど偏りが見られる。ささらに独り言は 言うのに会話しない, あるいは会話のルールがわからないなどさまざまなレベルでの言語使用 の障害がその特徴となっている。その背景には中枢性統合理論と親和性の高い低連結性理論や 社会脳の障害など脳の情報処理の違いが論じられている。ささまざまな高次脳機能障害を併せも つ自閉症スペクトラムの言語訓練は神経心理学的検査などの包括的な評価を基に, その障害特 徵を考慮し効果的に行えるよう工夫が必要になる。

索引用語：自閉症スペクトラム, 脳機能, 低連結性, 社会脳, 神経心理学的検査

\section{Communication Impairment in Children with Autism Spectrum Disorders}

Kanae Fujihara

\begin{abstract}
Communication deficits in autism spectrum disorders (ASD) are not uniform, as seen in poor comprehension of complex sentences and metaphors combined with good vocabulary, spelling and phonological ability. It is also known that ASD patients have difficulty in use of language such that they do not speak to others though they speak to themselves or that they cannot follow conversational rules. Underconnectivity theory, which has high affinity with central coherence theory, and social brain disorder theory suggest that the deficits come from differences in brain functions. Comprehensive neuropsychological examination will be useful to understand cognitive characteristics of ASD individuals, and an effective speech and communication therapy requires coping with the cognitive characteristics.
\end{abstract}

Key words: autism spectrum disorder, brain function, underconnectivity, social brain, neuropsychological examination

Kanner ${ }^{1)}$ は「人との情緒的な接触が困難, 極端な 孤立」話し言葉がない,あるいは意思疎通ができない」 「同一性保持への強い欲求」「物を巧みに操作し没頭す る」などの特徵をもつ子どもたちを「早期乳幼児自閉 症」と名づけた。ほとんど同時期に Asperger ${ }^{2}$ は「人
との距離やマナーなど社会性の困難」「特定の物への 限局した強い興味」「相互的な会話の困難」などで特 徵づけられる子どもたちを「小坚期の自閉的精神病質」

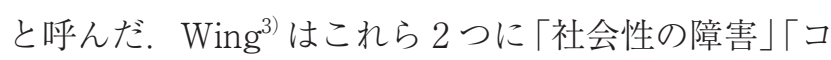
ミュニケーションの障害」「イマジネーション（想像

東北文化学園大学医療福祉学部リハビリテーション学科言語聴覚学：干981-8551 仙台市青葉区国見 6-45-1

Speech-Pathology and Hearing Course, Department of Rehabilitation, Faculty of Medical Science and Welfare, Tohoku Bunka Gakuen University: Kunimi 6-45-1, Aoba-ku, Sendai, Miyagi 981-8551, Japan

2010 年 2 月 24 日受理 
表 1 自閉症スペクトラム (ASD)

\begin{tabular}{l}
\hline ·社会性の障害 \\
·コミュニケーションの障害 \\
・イマジネーション (想像力, 思考の柔軟性) の障害 \\
\hline
\end{tabular}

(Wing, 1979)

力, 思考の柔軟性）の障害」という共通性を見出し,「自 閉症スペクトラム」としてまとめた（表 1)。DSMIVでは対人関係の質的障害を中核とする広沉性発達障 害の下位グループとして自閉性障害，レット障害，小 児崩壊性障害, アスペルガー障害，特定不能の広汎性 発達障害が含まれている。現在，レット障害と小児崩 壊性障害はその経過が異なるので，これを除いた残り の3つを自閉症スペクトラムと呼ぶことが多い.ここ でもその呼び方を採用する。

自閉症スペクトラムのコミュニケーション障害は前 言語期から認められる。非自閉症に比べ，人の顔や言 語音に注意が向きにくく，模倣の遅れや顔の表情認知 の遅れが見られ，また，言語習得に深く関係してい ると考えられている共同注意の遅れも報告されてい

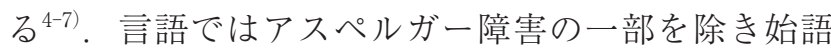
が遅れ，話し言葉を獲得しない場合もある ${ }^{8)}$ 。言語の 形式の側面では語彙，つづり，音韻分析など 1 対 1 対 応で対応可能なものは良好な傾向があり ${ }^{9)}$, 逆に複雑 な文の理解は困難なことが多い ${ }^{10)}$. 同様の理由から隠 喻や皮肉の理解は特に難しくなる11)。しかし，自閉症 スペクトラムのコミュニケーション障害の特徵はやは りその言語使用にある。幼坚期に見られる知的障害を 伴わない言語障害である受容性言語発達障害との比較 でも言語機能の異常が自閉症スペクトラムを分けてい た ${ }^{1213)}$. 独り言は言うのに人に向けて言葉を使わない などコミュニケーションを目的とした発話が少ない． また，使うようになった場合でも，「要求」のように 結果がはっきり見える言語機能に偏る傾向がある。さ らに, 流暢に話す場合でも，一方的に話すなど，トピッ クの維持や話者交代などの会話のルールを守るのが困 難なことが多い.

このようなコミュニケーション障害はなぜ起こるの であろうか? 近年, 自閉症スペクトラムの脳機能が 定型発達のそれと異なることが知られてきている。言 語もその例外ではない. Justら ${ }^{14)}$ は統語的に単純と考 えられる能動文への質問（例：そのシェフは父に感謝 した。感謝したのは？シェフ一父）とより複雑と考 えられる受動文への質問（例：その編集長は秘書に助 けられた，助けたのは？編集長一秘書) を視覚提示
し, 判断する課題を高機能自閉症群と定型発達群に課 し，その fMRI を比較した。 その結果, 高機能自閉症 群では語彙や音韻機能と関係が深いと考えられる傊頭 葉で，より活動が見られ，統語など，より複雑な情報 の統合に関係すると推測される前頭葉では定型発達群 に比べ賦活が少なかったと報告している。さらに，み ずからが自閉症スペクトラムであるテンプル・グラン デン博士もその著書の中で「私は画像で思考する」と 述べるなど，情報処理の質的違いの可能性も示唆さ れている ${ }^{15)}$. Kana ${ }^{16)}$ は低イメージ文 (例：足し算, 引き算, 掛け算は算術です) と高イメージ文（例：数 字の 8 は 90 度回転させるとメガネに見えます）を高 機能自閉症と定型発達群で比較したところ, 高機能自 閉症のみで低イメージ文でも視空間情報処理に関係し ていると考えられる部位が賦活した。このことは自閉 症スペクトラムで質的に異なる言語情報の処理が行わ れている可能性を示唆している.

これらの研究が共通して支持しているのが自閉症の 低連結性 (underconnectivity) 仮説である ${ }^{17)}$ 。自閉症 の脳の器質的異常については小脳をはじめさまざまな 部位が報告されているが，Belmnte らは自閉症の脳で は視覚領域と聴覚領域など異なる様式の領域や前頭葉 と頭頂葉などを結ぶ連合繊維，また右脳と左脳を結ぶ 交連繊維など遠距離の結合が少ないことを示し，質の 異なる情報を統合する処理が低下している可能性を示 唆した。この仮説は Frith ${ }^{18)}$ の中枢性統合理論 (central coherence）とも矛盾しない，中枢性統合とは定型発 達で見られる情報処理過程の特徵の一つで情報を統合 して，文脈の中でより高次の意味を構築する傾向を指 すＦrith は自閉症では中枢性統合がうまく働かず， トップダウンの統制がきかず，抹消の情報は統合され ないため，全体的な意味の抽出が困難になり，結果と して経験や思考の断片化が起こると考えた。自閉症者 では全体的な情報処理（global processing）よりも部 分的な情報処理（local processing）や細部に焦点を当 てた情報処理（detail-focused processing）を好む傾 向があることもこれと一致している ${ }^{19)}$.また, 高機能 自閉症の $70 \%$ 以上でさまざまな情報を統合して, 計 画を立て効率良く遂行する能力，実行機能に障害が見 られることも20)これを支持している．自閉症スペク トラムで抽象的な意味理解, 複雑な文の意味理解が困 難なこと, 同時に部分的な情報処理で対応可能な語彙, つづり，音韻処理等は良好なことをよく説明する。

他方，人の顔や言語音へ注意が向きにくい，表情認 知の困難，共同注意の遅れ，言語使用の障害などは低 


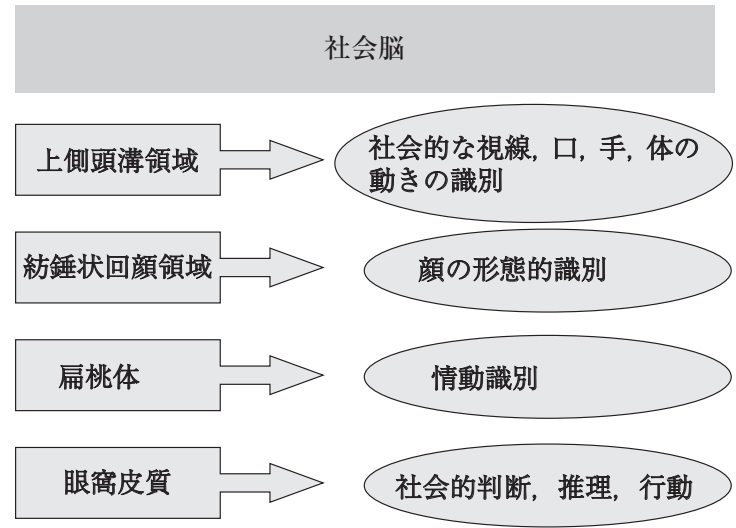

図 1 社会脳の主な部位と機能

連結性のみでは説明が難しい。これらを説明するも のとして「社会脳」障害説がある ${ }^{21}$ 。社会脳とは他者 の目的, 意図, 信念, 推論の情報処理機能（「心の理 論」)，心理的相互交流を支えると考えられる脳で，上 側頭回領域, 紡錘状回, 扁桃体, 眼窩前頭皮質を中心 とするネットワークを指す。上側頭回領域は社会的視 線，口，手，体の動きの識別，紡錘状回は顔の形態的 識別, 扁桃体は情動識別, 眼窩前頭皮質は社会的判断, 推理を担っていると考えられている（図 1). 自閉症 スペクトラムではこの社会脳の機能が障害されている 可能性が示唆されている。扁桃体に関しては, 生後直 後に両側扁桃体を吸引除去したサルで社会的孤立，ア イコンタクトの欠如，常同運動など自閉症スペクトラ 厶の特徵と共通する症状が見られる ${ }^{22}$ 。 また，自閉症 スペクトラムでは人の目から心理状態を推測する課題 で fMRI 上，扁桃体の賦活がそしいなどの報告がある 23). さらに紡錘状回の顔領域（FFA）の顔知覚課題 で活動性の低下が見られ，これと自閉症スペクトラム の社会性障害との間に相関が認められている ${ }^{24)}$.

このほかに自閉症スペクトラムの「相手の意図を読 み取る」「共感」「内省」「模倣」「言語」の障害をミ ラー・ニューロンの障害で説明しょうとするものもあ る25)。 ミラー・ニューロンとは相手の動作を見るだけ で自分がその動作をしたときと同じょうに活動する ニューロンでサルでその存在が確認されている。 人で も下前頭回, 下頭頂葉, 上側頭溝, 辺縁系（带状回前 部など）などにミラー・ニューロンがあると推測され ている ${ }^{26)}$ ，人では自分が動作をしたり，相手の動作を 見るときに抑制される脳波（ミュー波）を使い，間接 的にミラー・ニューロンの働きを見ている，その結果， 自閉症スペクトラムでは自分の動作ではミュー波の抑 制は見られるが，相手の動作を見ているときにはこれ
が見られず，ミラー・ニューロン・システムがうまく 働いていない可能性が報告されている27).

これらの知見は自閉症スペクトラムのコミュニケー ション障害支援で留意すべき点をいくつか示唆してい る。まず，自閉症スペクトラムでは定型発達には生得 的にある人への関心が昰しいので，子供たち自身が快 を感じる対人交流経験の場を意識して提供することか ら始める必要がある。それは予測可能な安心できる環 境での理解できる交流であり，そこでわかるように伝 えられる経験と伝えると便利だという経験を積むこと であろう，わかるように伝える工夫としては，情報の 統合を必要とする抽象的な表現を避け絵に描くように 伝える，たとえば「ちょっと待って」のように抽象的 な表現ではなく「この椅子に座ってタイマーが鳴るま でこの本を読んでいて」と具体的に伝える，また，言 葉の理解がない時点では言葉かけを避け，子供がわか る手段，たとえば実物，絵や写真などを使って伝える 工夫も必要となる。TEACCH の構造化はこれによく 合致する。また，人との交流自体に快を感じにくい子 供たちなので，人に伝えると自分が欲しいものが得ら れる状況を作るなど，発信する動機づけの工夫が必要 になる，言葉がない時点からカードを渡すと欲しいも のが得られる経験を積む PECS はその1例であろう。 話すようになっても，要求だけでなく，拒否，情報請 求，情報提供などさまざまな機能に使えるよう支援し ていくことが大切である，さらに，顔から感情を読み 取る練習, 視線やジェスチャーのもつ意味を理解し使 う練習，会話のルールを守る練習，相手の気持ちを理 解し対応する練習などが必要と考えられる.

自閉症スペクトラムの高次脳機能障害は言語・コ ミュニケーションのみではなく, 感覚, 認知, 記憶, 実行機能, 構成行為, 微細運動など広沉な障害が見ら れるので, 言語訓練を行う際も，その障害特徵に配慮 する必要がある，さらに個人の発達レベル，特徵も加 わるので，その評価は包括的で詳細でなければならな い. 従来, 脳損傷への脳機能評価として活用されてき た心理学的検查が，これら自閉症スペクトラムの広沉 な脳機能障害を評価するにも適している，最後に言語 の聴覚理解が 2 歳代, 仮名単語の読解がある程度可 能なのにもかかわらず，対人への発声がなくジェス チャーも数個しかない 5 歳女児への言語訓練の自験例 を簡単に紹介する。

症例は 3 歳 6 力月で広沉性発達障害と診断された女 児で，脳波および頭部 CT ・ SPEC で異常を認めない. 療育手帳再判定のために来所，保護者の希望により言 


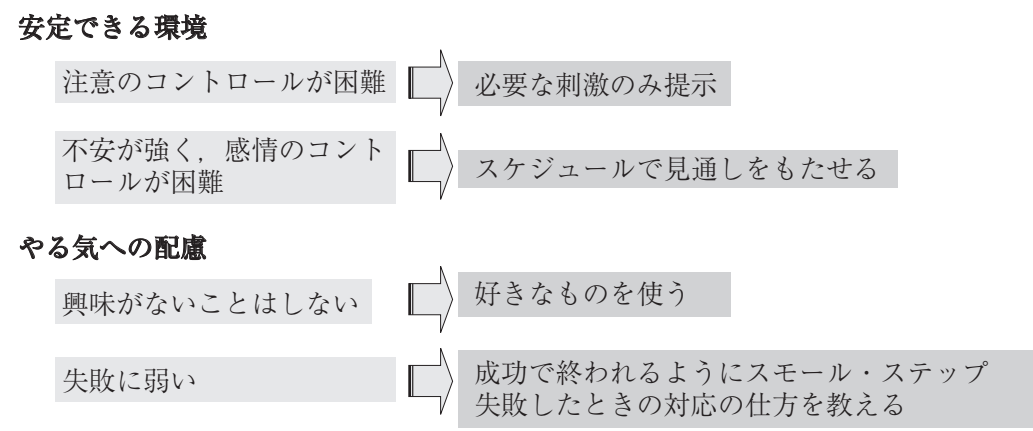

\section{般化への配慮}

修正, 応用が苦手

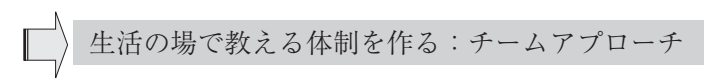

図 2 自閉症スペクトラム児への言語訓練 障害特徵への配慮

語訓練を行うこととなった。独り言（喃語）や泣き声 では発声が認められたがコミュニケーションとしての 発声はなかったので，声を使ってコミュニケーション する訓練を中心に行った。発声すると欲しいものが得 られる経験を積むことから始め，その後は得意な文字 を活用しての構音訓練を取り入れ，さらに症例が好 きな童話の劇をするなどして会話の訓練へと進んだ. 月 2 回, 約 1 年の訓練で呼びかけ, 要求, 拒否, 返事 などで発話が見られるようになった。構音では母音, $/ \mathrm{m} /$ や $/ \mathrm{p} /$ などの両唇音, / t / は発音可能となったが, 一貫性に乏しい音の誤りが見られ，また，音節（モー ラ）ごとに区切って発話するなど，成人の脳損傷で見 られる発語失行に類似した症状が続いた。訓練は就学 のため終了となった。 2 年後, 療育手帳再判定のため の来所時には，書字 (平仮名) や五十音表を指さして 簡単な情報を伝えるようになり，また，音節ごとに区 切るゆっくりで不明瞭な発話ではあるが, 自発話も増 えていた。他方，構音のできる音の種類は訓練終了時 と殆ど変化がなかった。夏休みを利用して訓練を再開 すると発音できる音は短期間に確実に増えるが，その 後も, 自力で新しい構音を獲得することはなかった. この傾向はそれからも続き，自閉症スペクトラムの障 害特徴の一つである「みずから新しいことにチャレン ジすること」や「自分の行動をモニターして修正する こと」が困難であることが影響していると考えられた。 また，効果的に訓練を行うためには障害特徴に配慮し てのさまざまな工夫が必要であった。第一に注目して ほしい刺激のみを提示するなどして注意コントロール の困難に対応するとともに，スケジュール等を活用し 見通しをもたせるなどして安定できる環境を整える必 要があった。さらに上手に話したいといった内的動機
づけがそしいので，興味のあるものを教材に用いて モーティベーションを高め, 課題はスモールステップ を心がけ常に成功で終わるようにするなどやる気への 配慮が不可欠であった。また, 般化が困難であるので, 実用化に向け保育士や保護者と連携を取り，生活の場 でも訓練するようにした（図 2 ).

以上, 自閉症スペクトラムの言語・コミュニケー ション訓練は通常の訓練プログラムをそのまま適応す ることは困難であり，神経心理学的検査などを用いて 個々の高次脳機能障害を詳細に評価し, その障害特徵 を考慮してさまざまな工夫を駆使することが必要と考 える。

\section{文献}

1) Kanner L: Autistic disturbances of affective contact. Nervous Child, 2: 217-250, 1943.

2) Asperger H: Die 'Autistischen Psychopathen' in Kindesalter. Archiv ur Psychiatrie und Nevenkrankheiten, 117: 76-136, 1944.

3) Wing L and Gould J: Severe impairments of social interaction and associated abnormalities in children: epidemiology and classification. Journal of Autism and Childhood Schizoprenia, 9: 11-29, 1979.

4) Swettenham J, Baron-Cohen S, Charman T, et al: The frequency and distribution of spontaneous attention shifts between social and nonsocial stimuli in autistic, typically developing, and nonautistic developmentally delayed infants. J Child Psychol Psychiatry, 39(5): 747-753, 1998.

5) Williams JH, Whiten A and Singh T: A systematic review of action in autistic spectrum disorders. J Autism Dev Disord, 34: 285-299, 2004.

6) Klin A, Sparrow SS, de Bildt A, et al: Anomed study of face recognition in autism and related disorders. J Autism Dev Disord, 29(6): 499-508, 1999.

7) Osterling J and Dawson G: Early recognition of children 
with autism: a study of first birthday home videotapes. J Autism Dev Disord, 24(3): 247-257, 1994.

8) Fombome E: The epidemiology of autism: A revies. Psychol Med, 29: 769-789, 1999.

9) Walenski M, Mostofsky SH, Gidley-Larson JC, et al: Brief report: enhanced picture naming in autism. J Austism Dev Disord, 38: 1395-1399, 2008.

10) Minshew NJ, Goldstein G and Siegel DJ: Neuropsychologic functioning in autism: profile of a complex information processing disorder. J Int Neuropsychol Soc, 3: 303-316, 1997.

11) Happe FG: Communicative competence and theory of mind in autism: a test of relevance theory. Cognition, 48: 101-119, 1993.

12) Cantwell D, Baker L and Rutter M: A comparabative study of infantile autim and specific developmental receptive language disorder-IV. Analysis of syntax and language function. J Child Psycol Psychiat, 19: 351-362, 1978.

13) Tager-Flusterg H, Paul R and Lord CE: Language and communication in autism. Handbook of Auatism and Pervasive Developmental Disorder: Vol. 1 (edited by Volkmar F, et al), New York, Wiley, pp 335-364, 2005.

14) Just MA, Cherkassky VL, Keller TA, et al: Cortical activation and synchronization during sentence comprehension in high-functioning autism: evidence of underconnectivity. Brain, 127: 1811-1821, 2004.

15) Grandin T: Thinking in Pictures and Other Reports from my Life with Autism, New York, Doubleday, 1995.

16) Kana RK, Keller TA, Cherkassy VL, et al: Sentence comprehension in autism: thinking in pictures with decreased functional connectivity. Brain, 129: 2482-2493, 2006.

17) Belmnte MK, Allen G, Becker-Mitchener A, et al: Autism and abnormal development of brain connectivity. J of Neuroscience, 24: 9228-9231, 2004.

18) Frith U: Autism Explaining the Enigma, Oxford, Basil Blackwell, 1989.

19) Happe E: Autism: Cognitive deficit or cognitive style. Trends Cogn Sci, 3: 216-222, 1999.

20）太田昌孝：自閉症圈障害における実行機能. 自閉症と発達 障害研究の進歩, 7:3-23, 2003.

21) Brothers L: The social brain: a project for integrating primate behavior and neurophysiology in a new domain. Concepts Neurosci, 1: 27-51, 1990.

22) Bachevalier J: Medial temporal lobe structures and autism: a review of clinical and experimental findings. Neuropsychol, 32: 627-648, 1994.

23) Baron-Cohen S, Ring HA, Wheelwrght S, et al: Social intelligence in the normal and autistic brain: an fMRI study. Eur J Neurosci, 11: 1891-1898, 1999.

24) Critchley HD, Daly EM, Bullmore ET, et al: The functional neuroanatomy of social behavior: changes in cerebral blood flow when people with autistic disorder process facial expressions. Brain, 123: 2203-2212, 2000.

25) Ramachandran VR and klOberman LM: Broken Mirrors: A theory of autism. Sci Am, 63-68, 2006.

26) Rizzolatti $G$ and Craighero L: The mirror neuron system. Annu Rev Neurosci, 27: 169-192, 2004.

27) Oberman LM, Hbbard EM, McCleery JP, et al: EEG evidence for mirror neuron dysfunction in autism spectrum disorders. Brein Res Cogn Brain Res, 24: 190198, 2005.

\footnotetext{
別刷請求先：干981-8551 仙台市青葉区国見 6-45-1 東北文化学園大学医療福祉学部リハビリ テーション学科言語聴覚学 藤原加奈江
} 